\title{
Fluctuation of iron carrying capacity in an elite female triathlete while maintaining sporting performance
}

\author{
Alberto GARCÍA BATALLER 1, Nicola MAFFULLI 2, José L. NEYRO ${ }^{3}$, \\ Johnny PADULO 4, 5, Juan M. SANTISTEBAN MARTÍNEZ 6, Nicola L. BRAGAZZI 4 *, \\ Francisco J. CALDERÓN MONTERO 1
}

${ }^{1}$ Department of Health and Human Performance, School of Physical Activity and Sport Sciences (INEF), Polytechnic University of Madrid, Madrid, Spain; ${ }^{2}$ Centre for Sports and Exercise Medicine, Queen Mary University of London, London, UK; ${ }^{3}$ Department of Obstetrics and Gynecology, Cruces University Hospital, University of País Vasco, EHU-UPV, Barakaldo, Spain; ${ }^{4}$ Faculty of Kinesiology, University of Split, Split, Croatia; 5 University e-campus, Novedrate, Como, Italy; ${ }^{6}$ Department of Medical Services, Athletic Club Bilbao, Bilbao, Spain

*Corresponding author: Nicola L. Bragazzi, Faculty of Kinesiology, University of Split, Split, Croatia.

E-mail: robertobragazzi@gmail.com

\begin{abstract}
A B S T R A C T
The prevalence of iron deficiency in adolescent female athletes is above $52 \%$ and is more frequent in endurance sports. Therefore, it is essential to monitor the training process in endurance athletes in order to follow their adaptation to the training load and avoid iron deficiency and, even, anemia. This article presents a clinical case study, which analyzes hematological parameters (namely, hemoglobin, hematocrit, number of erythrocytes and reticulocytes, mean corpuscular hemoglobin, mean cellular reticulocytes and the fluorescence of the reticulocytes) and iron parameters (including ferritin, transferin and haptoglobin) in an elite female triathlete ( $7^{\text {th }}$ in the Athens Olympic Games, among other relevant sport results) during 9 consecutive seasons (from 2004 to 2012). Training load was measured in each complete training session using "training impulse" (TRIMP). In order to avoid anemia and maintain competitive level, 100 to $220 \mathrm{mg}^{\circ} \mathrm{FeSO}_{4}$ were administered daily during her whole sports career. The triathlete did not develop anemia in any of the 9 seasons, although mean hemoglobin concentration (13.08 g/dl) was only slightly above the limits defined for pseudoanemia (12 g/ dl). This case study could help sport managers and coaches in properly managing triathlon athletes.
\end{abstract}

KEY WORDS: Female; Athletes; Ferritins.

$\mathrm{T}$ he process of adapting to the training load in elite athletes is a complex phenomenon, given the demands of top level competition. Triathlon, an Olympic discipline, presents a great deal of difficulty as it is composed of three disciplines in which it is necessary to coordinate intensity and volume. According to O'Toole, ${ }^{1}$ a triathlete preparing for an Ironman competition trains on average $11.6 \mathrm{~km}$ of swimming $(3.5 \mathrm{~h}), 365 \mathrm{~km}$ of cycling (12.3 h) and $72.4 \mathrm{~km}$ of running (5.75 h) per week, training on average for more than 3 h per day. Gulbin and Gaffney ${ }^{2}$ have quantified training volume in a similar fashion: swimming $8.8 \mathrm{Km} /$ week, cycling $270 \mathrm{~km} /$ week and running $58.2 \mathrm{Km} /$ week. TRIMPS ${ }^{3}$ are used during one session and over several different training sessions to assess training load and monitor for possible overtraining. This method aims to quantify 


\section{COPYRIGHT $^{\circledR} 2019$ EDIZIONI MINERVA MEDICA}

and compare the effects of different training sessions of different durations and intensities using a single global training index. The result gives a measurement of the work done or the energy consumed when performing a determined task or training session.

Biological monitoring is equally important in elite athletes. It is difficult and complex to characterize the adaptation process using a blood test, and, more importantly, to prevent the insurgence of the overtraining syndrome, although different indices have been proposed to prevent its onset and to deal with prevention, diagnosis and treatment. ${ }^{4}$ Elite female athletes, as well having the inherent problems of any top performance athlete, have the added problem of possibly suffering from serious complications, one of which is known as the triad.5 An elite female athlete is more susceptible to being affected by one of the components of the triad ${ }^{5}$ or even all three components ${ }^{5,} 6$ having to reconcile sports performance with their health, especially in the long term. Female athletes frequently have hemoglobin values of less than $12 \mathrm{gr} / 100 \mathrm{ml}^{7}$ even though the incidence of a state of pseudoanemia is very varied. However, although the hemoglobin values of elite athletes are within the normal range, some authors cite very low ferritin values in around $82 \%$ of the women. ${ }^{8}$ Hyposideremia can be accentuated by menstruation as it is the main cause of iron deficiency in female athletes and sedentary counterparts. Blood loss of more than 60-80 $\mathrm{ml} /$ day inevitably leads to hyposideremia and a decrease in ferritin.?

For all of these reasons, we think that it is essential to monitor the variables, which can indicate that an elite female athlete may be suffering from one or all of the symptoms of the triad during her sporting career for maximum performance and, at the same time, so that the high training load does not affect health in the long term. Some studies have related hematological status with training, but have been carried out with non-elite athletes, ${ }^{9}$ with non-elite athletes in laboratory conditions, ${ }^{10,}, 11$ during a period of 20 days, ${ }^{12} 120$ days, ${ }^{13} 15$ months, ${ }^{14} 18$-20 months, ${ }^{15}$ 33 weeks and 7 hours/week, ${ }^{16}$ or in two training periods. ${ }^{17}$

However, we have found no study in the lit- erature which has monitored an athlete during 9 seasons. We believe that the case presented here is the only one in the world which has thoroughly monitored an elite female athlete during her entire sporting career, as she has now withdrawn from competition. This medical-sports clinical case has been carried out with the consent of the athlete herself and of her coach.

\section{Case report}

The subject is an elite female triathlete who was $7^{\text {th }}$ in the Olympic Games in Athens in 2004, $20^{\text {th }}$ in Beijing 2008, European Triathlon and Duathlon Champion, European Triathlon and Duathlon runner-up, twice bronze medalist in the World Duathlon Championships and 10 times in the TOP3 in Triathlon World Cups. The periodization of the season and consequently the medical monitoring of the athlete depended on the objectives set. For this reason the number of blood tests taken in the 9 seasons oscillated between 4 and 9. Anthropometric data of triathlete shown in Table I.

The season was divided into 3 macrocycles with a total of 51 microcycles. The first macrocycle was composed of 25 weeks and ended with the Madrid World Cup where she finished $3^{\text {rd }}$ and included a secondary objective which was the Spanish Duathlon Championship, which she won. During this cycle, microcycle 16 , she recorded her best time in the half marathon of $1: 15.23$. The second macrocycle ( 15 weeks) had as its objective the World Triathlon Championships in Hamburg. The last macrocycle (8 microcycles) had the objective of the World Cup in Aqaba. During this period she attended seven training camps in Sierra Nevada at 2,350 meters: 5 in weeks 3, 4, 8, 9 and 10 (macrocyle 1), 2 in weeks 30 and 31 (macrocycle 2). During weeks 11 to 25 (microcycle 1) she slept in a normoxic bed an average of 9 hours a night and with an $\mathrm{O}_{2}$ concentration equivalent to an altitude of 3,000 meters. Finally, she was administered sessions of intermittent hypoxia equivalent to an altitude of between 4,000 and 6,000 meters (from week 1 to week 39) lasting $75^{\prime}$ and work intervals of 6 ' with 4' rest.

Table II shows the training load for each tri- 


\section{COPYRIGHT $^{\circledR} 2019$ EDIZIONI MINERVA MEDICA}

TABLE I.-Anthropometric data of triathlete during sport career.

\begin{tabular}{|c|c|c|c|c|c|c|c|c|}
\hline \multirow{2}{*}{$\begin{array}{l}\text { Anthropometric parameter } \\
\text { (unit of measurement) }\end{array}$} & \multicolumn{8}{|c|}{ Year } \\
\hline & 2001 & 2002 & 2003 & 2004 & 2005 & 2006 & 2007 & $\begin{array}{c}2016 \\
\text { (retired) }\end{array}$ \\
\hline Body mass (Kg) & 51.4 & 51.3 & 52.40 & 51.8 & 51.7 & 50.8 & 50.8 & 50.9 \\
\hline Fat $(\%)$ & 13.1 & 12.9 & 13.03 & 13.1 & 13.0 & 13.2 & 12.6 & 12.84 \\
\hline Muscle body mass (Kg) & 47.9 & 47.8 & & 47.9 & 48.0 & 47.5 & 48.0 & 47.83 \\
\hline Medial calf skeefold (mm) & 24.3 & 24.0 & & 24.5 & 23.9 & 24.7 & 22.3 & 23.2 \\
\hline E6 (mm) & 40.1 & 39.8 & & 40.8 & 40.8 & 38.9 & 36.3 & 35.73 \\
\hline $\mathrm{E} 8(\mathrm{~mm})$ & 51.4 & 50.1 & & 50.6 & 50.8 & 49.3 & 46.1 & 44.8 \\
\hline Front thigh skinfold (mm) & 3.0 & 3.3 & & 3.3 & 3 & 3.8 & & 2.9 \\
\hline Iliac crest skinfold (mm) & 7.4 & 6.8 & & 6.9 & 6.95 & 7.6 & 7.2 & 6.5 \\
\hline Iliac crest skinfold (mm) & 5.4 & 5.1 & & 5.4 & 5.35 & 5.65 & 4.9 & 4.6 \\
\hline Abdominal skinfold (mm) & 5.5 & 5.9 & & 6.2 & 6.25 & 6.85 & 6.0 & 5.8 \\
\hline Biceps skinfold (mm) & 3.2 & 3.0 & & 2.9 & 3.05 & 2.7 & 2.5 & 2.6 \\
\hline Triceps skinfold (mm) & 6.5 & 6.6 & & 6.7 & 6.1 & 5.7 & 5.2 & 6.8 \\
\hline Subscapular skinfold (mm) & 6.6 & 6.6 & & 6.3 & 6.2 & 6.45 & 6.1 & 6 \\
\hline Front thigh skinfold (mm) & 9.3 & 8.9 & & 10.3 & 10.35 & 8.5 & 8.7 & 9.1 \\
\hline
\end{tabular}

TABLE II.-Training load (measured in Trimps, according to Banister, 1992) for each of the disciplines and for the total event.

\begin{tabular}{lcccc}
\hline Month & Cycling & Running & Swimming & Total \\
\hline January & 2119 & 1744 & 2229 & 6092 \\
February & 2335 & 1577 & 2945 & 6857 \\
March & 2221 & 1612 & 3200 & 7033 \\
April & 2400 & 1825 & 2360 & 6585 \\
May ** & 2020 & 1425 & 1930 & 5375 \\
June & 2100 & 1600 & 2129 & 5829 \\
July & 2525 & 1915 & 2563 & 7003 \\
August & 2360 & 1880 & 2325 & 6565 \\
September *** & 1985 & 1320 & 1850 & 5155 \\
October & 2232 & 1612 & 2235 & 6079 \\
November * & 1620 & 1312 & 1520 & 4452 \\
\hline
\end{tabular}

*3 weeks; ** final macrocycle 1; *** final macrocycle 2 .

athlon discipline and for the total event, according to Banister (1999).

$$
T I=T \cdot \Delta H R \text { (equation } 1)
$$

where $\mathrm{TI}$ is the adimensional training impulse, $\mathrm{T}$ is the duration of the exercise in min and $\Delta \mathrm{HR}$ $=$ fractional elevation in HR or HR reserve.

$\triangle H R$ is calculated using the following formula:

$$
\Delta H R=(\text { Exercise } H R-\text { Resting } H R) /
$$

(Maximum HR - Resting HR) (equation 2)

Equation 1 should be corrected due to the possible deviations that can be produced by the two factors.

The correction factor for women is:

Correction Factor $=0.86$.

$e^{1.67 \cdot f a r c t i o n a l ~ e l e v a t i o n ~ i n ~ H R ~ o r ~ H R ~ r e s e r v e ~(e q u a t i o n ~} 3$ )
By combining equations 1 and 3 , the equation proposed for calculating the TRIMPS, is:

$$
\begin{gathered}
I E=(\text { Exercise HR - Resting HR) / (Maximum } \\
H R-\text { Resting HR) } 0.86 \text { e (Exercise HR - Resting HR) / } \\
\text { (Maximum HR - Resting HR) (equation 4) }
\end{gathered}
$$

To calculate the Banister index all the sessions were recorded for each one of the disciplines using a heart rate monitor (Suunto model t6), resting heart rate was recorded in the morning and maximum exercise heart rate was measured using specific field tests for each discipline. The annual mean for resting hear rate was 46 lat $/ \mathrm{min}$ and maximum heart rate recorded for each discipline was: 184 (cycling), 192 (running) and 186 (swimming).

In her medical history the athlete indicated that she had no family or personal history of impaired iron homeostasis, due to deficiency (anemia) or excess (hemochromatosis), which was confirmed by the blood test results obtained during her sporting career.

Table II shows the training load, while Table III shows the mean values for the red blood cells and iron status during the 9 seasons and when the subject retired from competition.

Figure 1 shows the average values for erythrocytes and hemoglobin concentration for each of the 9 seasons during which the athlete was at the elite level. Figure 2 shows the mean values for ferritin and iron concentration during her whole sporting career. It is interesting to note how from the 2007 season on the parameters shown in Fig- 


\section{COPYRIGHT $^{\odot} 2019$ EDIZIONI MINERVA MEDICA}

TABLE III.-Mean values for the red blood cells and iron status during the 9 seasons.

\begin{tabular}{|c|c|c|c|}
\hline & Mean values for 9 seasons & $\begin{array}{l}\text { Values when the } \\
\text { triathlete had retired }\end{array}$ & $\begin{array}{l}\text { Cut-off values for women } \\
\text { or women athletes }\end{array}$ \\
\hline Milions $/ \mathrm{mm}^{3}$ & $4.15 \pm 0.13$ & 4.32 & $>120 \mathrm{~g} / \mathrm{l}$ \\
\hline Hemoglobin & $13.08 \pm 0.31$ & 13.1 & $14 \pm 2$ \\
\hline HEMATOCRIT (\%) & $38.03 \pm 1.04$ & 38.3 & 42 \\
\hline MCV (fl) & $85.30 \pm 2.53$ & 88.8 & $>80$ \\
\hline $\mathrm{MCH}(\mathrm{pg})$ & $29.33 \pm 0.76$ & 30.4 & $>28$ \\
\hline CHCM (gr/dl & $32.40 \pm 0.67$ & 34.2 & $34 \pm 2$ \\
\hline Reticulocyte count, absolute & $48.6 / \mathrm{mm}^{3}$ & 56.7 & $20-100\left(\times 10^{9} / 1\right)$ \\
\hline $\mathrm{MCVr},(\mathrm{fl})$ & $95.02 \pm 2.76$ & 99.2 & $92.4-120.2$ \\
\hline CHr. (pg) & $30.73 \pm 2.96$ & 32.7 & $26.7-33.0$ \\
\hline LFR $(\%)$ & $82.84 \pm 2.73$ & 86.7 & $81.0-96.4$ \\
\hline $\operatorname{MFR}(\%)$ & $8.98 \pm 0,27$ & 11.4 & $1.1-15.2$ \\
\hline HFR $(\%)$ & $1.26 \pm 0.14$ & 1.8 & $0.03-3.95$ \\
\hline IRON (mg/dl) & $110.07 \pm 4.46$ & 127.7 & \\
\hline FERRITIN (ngr/l) & $210.22 \pm 11.07$ & 32.3 & $10-170$ \\
\hline TRANSFERRIN & $114.38 \pm 33.72$ & 220 & $\begin{array}{l}60-140 \mathrm{mg} / \mathrm{dl} \\
11-25(\mathrm{mmol} / \mathrm{l})\end{array}$ \\
\hline HAPTOGLOBIN & $42.12 \pm 10.86$ & & $0,0.38-2.08$ \\
\hline
\end{tabular}

MCH: mean cellular hemoglobin; MCV: mean cellular volume; MCH: Mean corpuscular hemoglobin; MCVr: Mean cellular volume of reticulocytes; $\mathrm{CHr}$ : Amount of $\mathrm{Hb}$ in reticulocytes.

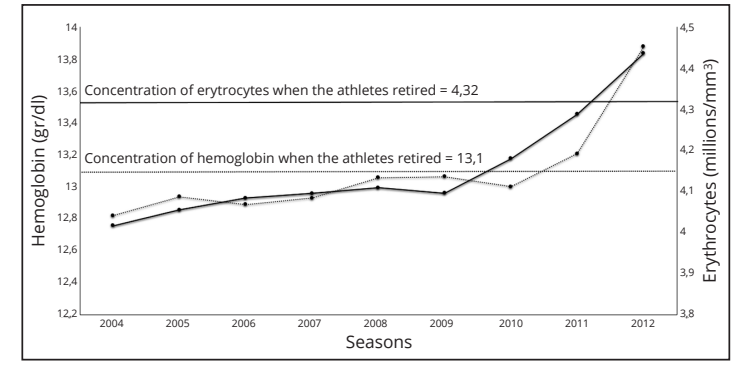

Figure 1.-Average values for erythrocytes and hemoglobin concentration.

ure 1, 2 began to increase. This was due to the fact that after that date the training load gradually decreased. All the research was performed in the laboratory of the High Council for Sport, an accredited center for the evaluation of elite athletes in Spain.

\section{Discussion}

Although during the 9 seasons the triathlete always had values for erythrocytes and hemoglobin concentration which were under the levels she recorded when untrained, we consider that she was at the limit of pseudoanemia, given that her mean hemoglobin value during the 9 seasons was $13.08 \pm 0.29$, always above $12 \mathrm{~g} / \mathrm{dL}$ which some authors define as pseudoanemia. ${ }^{7}$ We there-

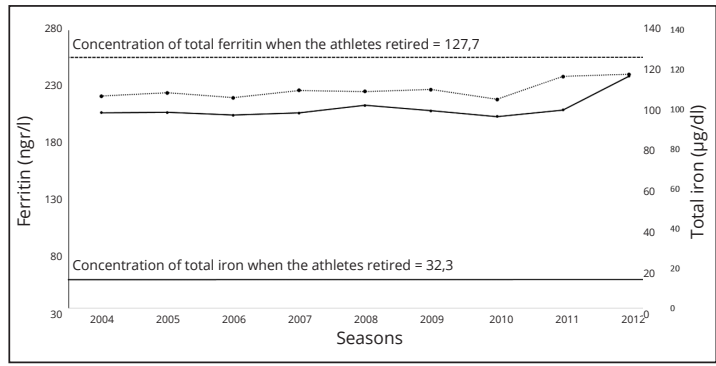

Figure 2.- Mean values for ferritin and iron concentration.

fore believe that during her era as an elite athlete a balance was obtained between erythropoiesis and the mechanisms which in part explain athletic pseudoanemia.

The subject maintained a mean value for ferritin $(210.22 \pm 11.07)$ which was well above the critical values considered as pseudoanemia. Furthermore, the mean value of transferrin saturation during the 9 seasons was above $100 \%$ $(114.38 \pm 33.72)$. These values were obtained with adequate therapeutic measures consisting of the ingestion of 100-200 mg of ferrous sulphate/ day, which produced no gastrointestinal problems given the lesser presence of side effects and the enhanced intestinal absorption achieved with supplementation with ferrous salts compared to ferric salts. This supplementary measure com- 


\section{COPYRIGHT $^{\circ} 2019$ EDIZIONI MINERVA MEDICA}

pensated for the normal losses and those caused by exercise. It is well known that exercise produces hemolysis, due to a mechanical effect, ${ }^{18}$ which leads to modifications of the erythrocyte membrane, ${ }^{19-21}$ or to activation of the molecules related with inflammation or release of stress proteins $^{22,23}$ or to both mechanisms. ${ }^{24,25}$

During her competitive career the triathlete did not suffer any gastrointestinal symptoms which could have indicated a loss of blood neither did any of the urine analyses show hematuria. In fact the mean levels of haptoglobin increased. The main function of haptoglobin, an sialoprotein, is to join with hemoglobin to prevent the loss of iron through the kidneys. ${ }^{22}$ It is true that there are differences in the concentration due to the three known phenotypes of haptogobin, ${ }^{23}$ but in no case were the values measured during the 9 seasons (42.12 \pm 10.86$)$ higher than normal (0.57$2.27 \mathrm{~g} / \mathrm{L})$. These values indicate a good hepatic response to the inflammatory stimulus and an adjustment to the hemolysis produced during exercise.

Mean values of reticulocytes during the 9 seasons were $48.6 / \mathrm{mm}^{3}$, although this parameter showed great variation $\left(34.5\right.$ to $\left.74.2 / \mathrm{mm}^{3}\right)$ due to the previously mentioned considerations (training in hypoxia, sleeping in hypoxic tents, intermittent hypoxic sessions). Reticulocytes with a high degree of fluorescence indicate a high level of immaturity (high ARN content). However, the values oscillated between 0.98 (2011) and 1.35 (2008) due to the above mentioned considerations. The increase in haptoglobin values over the 9 seasons is interesting as it could suggest a good response from the liver to the inflammatory stimuli produced during exercise and the adjustment of the hemolysis after intense effort. All these data indirectly suggest an adequate control of hepcidin synthesis and an improvement in other factors (hypoxia and inflammation) induced during intense exercise, which could influence this hormone. ${ }^{24,25}$

With regard to menstruation, until the 2007 season no special measures were taken because the triathlete had normal menstruation and the losses did not affect the red blood cells. Menstruation can provoke physiological changes like: thirst, changes in appetite, increase in weight, headache, swollen limbs, aches and pains, fatigue, skin problems, gastrointestinal symptoms or abdominal pain. But apart from these, the truth is that the psychological component can become very important, to the extent of constituting a syndrome, the premenstrual syndrome. ${ }^{26}$ Due to this it was decided to administer oral contraceptives in order to "program" menstruation with the Beijing Olympics in mind. In the middle of the Olympic preparation season, the triathlete indicated biomechanical impairments in swimming and running (a lack of propulsion). Although there appears to be no consensus ${ }^{27,28}$ it is thought that these biomechanical impairments could be influenced by the oral contraceptives and it was decided to withdraw the hormonal therapy. Once the therapy was discontinued the triathlete did not indicate a lack of propulsive capacity either in swimming or in running, so it was decided not to reintroduce the contraceptive therapy.

\section{Conclusions}

To summarize, an elite triathlete was biologically monitored for 9 seasons with a dual objective. Firstly to biologically monitor the assimilation of the high training regime which she would be performing as an elite athlete; and secondly to evaluate the possible repercussions of long term intense training to prevent her from suffering a possible anemia. Although she was always below the limits of biological adaptation, it has been demonstrated that these two objectives are not incompatible when adequate therapeutic and prophylactic measures are in place. The results suggest that the preventive treatment administered may be sufficient to prevent the apparition and development of anemia in female athletes.

\section{References}

1. O'Toole ML, Douglas PS, Hiller WD. Applied physiology of a triathlon. Sports Med 1989;8:201-25.

2. Gulbin JP, Gaffney PT. Ultraendurance triathlon participation: typical race preparation of lower level triathletes. J Sports Med Phys Fitness 1999;39:12-5.

3. Banister EW, Carter JB, Zarkadas PC. Training theory and taper: validation in triathlon athletes. Eur J Appl Physiol Occup Physiol 1999; 79:182-91. 


\section{COPYRIGHT $^{\circledR} 2019$ EDIZIONI MINERVA MEDICA}

4. Meeusen R, Duclos M, Foster C, Fry A, Gleeson M, Nieman D, et al.; European College of Sport Science; American College of Sports Medicine. Prevention, diagnosis, and treatment of the overtraining syndrome: joint consensus statement of the European College of Sport Science and the American College of Sports Medicine. Med Sci Sports Exerc 2013;45:186-205.

5. De Souza MJ, Nattiv A, Joy E, Misra M. Williams NI, Mallinson RJ, et al. 2014 Female Athlete Triad Coalition consensus statement on treatment and return to play of the female athlete triad: 1st International Conference held in San Francisco, CA, May 2012, and 2nd International Conference held in Indianapolis, IN, May 2013. Clin J Sport Med. 2014;24(2):96-119.

6. Deimel JF, Dunlap BJ. The female athlete triad. Clin Sports Med 2012;31:247-54.

7. Chatard JC, Mujika I, Guy C, Lacour JR. Anaemia and iron deficiency in athletes. Practical recommendations for treatment. Sports Med 1999;27:229-40.

8. Clement DB, Asmundson RC, Medhurst CW. Hemoglobin values: comparative survey of the 1976 Canadian Olympic team. Can Med Assoc J 1977;117:614-6.

9. Green HJ, Sutton JR, Coates G, Ali M, Jones S. Response of red cell and plasma volume to prolonged training in humans. J Appl Physiol (1985) 1991;70:1810-5.

10. Schmidt W, Maassen N, Trost F, Böning D. Training induced effects on blood volume, erythrocyte turnover and haemoglobin oxygen binding properties. Eur J Appl Physiol Occup Physiol 1988;57:490-8.

11. Banister EW, Hamilton CL. Variations in iron status with fatigue modelled from training in female distance runners. Eur J Appl Physiol Occup Physiol 1985;54:16-23.

12. Dressendorfer RH, Wade CE, Amsterdam EA. Development of of pseudoanemia in marathon runners during a 20-day road race. JAMA 1981;246:1215-8.

13. Balaban EP, Snell P, Stray-Gundersen J, Frenkel EP. The effect of running on serum and red cell ferritin. A longitudinal comparison. Int J Sports Med 1995;16:278-82.

14. Guglielmini C, Casoni I, Patracchini M, Manfredini F, Grazzi G, Ferrari M, et al. Reduction of $\mathrm{Hb}$ levels during the racing season in nonsideropenic professional cyclists. Int $\mathrm{J}$ Sports Med 1989;10:352-6.

15. Kaiser V, Janssen GM, van Wersch JW. Effect of training on red blood cell parameters and plasma ferritin: a transverse and a longitudinal approach. Int J Sports Med 1989;10(Suppl 3):S169-75.

16. Candau R, Busso T, Lacour JR. Effects of training on iron status in cross-country skiers. Eur J Appl Physiol Occup Physiol 1992;64:497-502.

17. Dufaux B, Hoederath A, Streitberger I, Hollmann W, Assmann G. Serum ferritin, transferrin, haptoglobin, and iron in middle- and long-distance runners, elite rowers, and professional racing cyclists. Int J Sports Med 1981;2:43-6.

18. Lippi G, Schena F, Salvagno GL, Aloe R, Banfi G, Guidi GC. Foot-strike haemolysis after a $60-\mathrm{km}$ ultramarathon. Blood Transfus 2012;10:377-83.

19. Brzeszczynska J, Pieniazek A, Gwozdzinski L, Gwozdzinski K, Jegier A. Structural alterations of erythrocyte membrane components induced by exhaustive exercise. Appl Physiol Nutr Metab 2008;33:1223-31.

20. Hanzawa K, Kai M, Hiraga A, Watanabe S. Fragility of red cells during exercise is affected by blood $\mathrm{pH}$ and temperature. Equine Vet J Suppl 1999;(30):610-1.

21. Jordan J, Kiernan W, Merker HJ, Wenzel M, Beneke R. Red cell membrane skeletal changes in marathon runners. Int J Sports Med 1998;19:16-9.

22. Giblett ER. The haptoglobin system. Ser Haematol 1968;1:3-20.

23. Langlois MR, Delanghe JR. Biological and clinical significance of haptoglobin polymorphism in humans. Clin Chem 1996;42:1589-600.

24. Peeling P, Dawson B, Goodman C, Landers G, Wiegerinck ET, Swinkels DW, et al. Cumulative effects of consecutive running sessions on hemolysis, inflammation and hepcidin activity. Eur J Appl Physiol 2009;106:51-9.

25. Suzuki K, Peake J, Nosaka K, Okutsu M, Abbiss CR, Surriano $\mathrm{R}$, et al. Changes in markers of muscle damage, inflammation and HSP70 after an Ironman Triathlon race. Eur J Appl Physiol 2006;98:525-34.

26. American College of Obstetricians and Gynecologist. Premenstrual syndrome. ACOG Practice Bulletin No.15. Washington, DC: ACOG, 2000.

27. Frankovich RJ, Lebrun CM. Menstrual cycle, contraception, and performance. Clin Sports Med 2000;19:251-71.

28. Hewett TE. Neuromuscular and hormonal factors associated with knee injuries in female athletes. Strategies for intervention. Sports Med 2000;29:313-27. 